\title{
Egyiptom szerepe a líbiai polgárháborúban
}

A líbiai válság közel egy évtizedes időszaka alatt a stabilizációs kísérletek sorra kudarcba fulladtak, aminek következményeként jelenleg a polgárháború harmadik szakasza dúl az országban. A konfliktus az egész térség stabilitását veszélyezteti, azonban Egyiptom számára kiemelt fenyegetést jelent, mert a két ország közel 1200 kilométeres határon osztozik, és Kairó számára korántsem mindegy, iszlamista szereplők esetlegesen milyen befolyást tudnak szerezni a térségben, mint ahogy a líbiai törzsszövetségek erőviszonya és a központi államhatalom müködőképessége sem.

Egyiptom Libiához hasonlóan érintett volt az arab tavasz okozta változásokban 2011 óta, de leküzdötte az átmenet és a hatalomváltás okozta belpolitikai válságot, majd a hatalmi visszarendeződés stabilizálta az országot. A líbiai helyzet Egyiptom számára kiemelt biztonsági fenyegetést jelent, de egyben lehetöséget is, mert a rendezésben való részvétellel erősítheti regionális befolyását és elősegíti külkapcsolatai épitését is, továbbá szerepvállalásával kül- és belpolitikai érdekeit is érvényesitit. A tanulmány azt vizsgálja meg, hogy az egyiptomi események hogyan befolyásolták a líbiai átalakulást 2011-et követően, illetve ezek a változások hogyan alakitották Kairó szerepvállalását a líbiai polgárháború három szakaszában.

Kulcsszavak: Líbia, arab tavasz, polgárháború, Egyiptom, Haftar, líbiai nemzeti egységkormány, Törökország, Oroszország

\section{Egypt's Role in the Libyan Civil War}

The Libyan crisis has been going on for almost a decade, during which period many stabilisation attempts have failed. As a result, we can currently witness the third phase of the Libyan civil war. The conflict threatens regional stability, moreover it is a major threat to Egypt, because the two countries share a nearly $1200 \mathrm{~km}$ long border, and it is not neutral to Cairo how much influence Islamist actors (might) gain throughout the region, nor is the fate of tribal alliances and the functioning of the central Libyan government.

Like Libya, Egypt was also involved in the transformations triggered by the Arab Spring since 2011, but could overcome the domestic crisis caused by the political transition as the political reorganisation stabilised the country. The Libyan situation poses a major threat to Egyptian security, but it is also an opportunity, because by participating in the settlement Egypt can strengthen its regional influence, deepen its foreign relations and advance both its foreign and domestic political interests as well. This study examines how the events in Egypt affected the Libyan transformation after 2011, and how political changes in Egypt changed Cairo's participation in the three phases of the Libyan civil war.

Keywords: Libya, Arab spring, civil war, Egypt, Haftar, Government of National Accord, Turkey, Russia

1 Ritter Noémi a Nemzeti Közszolgálati Egyetem Eötvös József Kutatóközpont Stratégiai Védelmi Kutatóintézet munkatársa. E-mail: ritter.noemi@uni-nke.hu 


\section{Bevezetés}

A líbiai helyzet alakulása meghatározó Kairó számára. A két arab állam történelmileg változó politikai kapcsolatai ellenére szorosan kötődik egymáshoz gazdasági, társadalmi és biztonsági aspektusból egyaránt. Az egyiptomi-líbiai határszakasz jelentős része sivatagos terület, amelyen keresztül szinte akadálymentes az illegális fegyver- és emberkereskedelem, illetve a szélsőséges csoportok átszivárgása. A polgárháborút megelőző években 1,5 millió egyiptomi állampolgár élt és dolgozott Líbiában, valamint az egyiptomi energiaellátás jelentős részét is az olcsó líbiai kőolaj biztosította. ${ }^{2}$ Líbia keleti területei (Kireneika) különösen fontosak Egyiptom számára: a keleti törzsek vezetőivel együttműködik az egyiptomi kormányzat, mert a közös határ védelmében fontos szerepet játszanak. ${ }^{3}$

Tanulmányomban azt vizsgálom, hogy a 2011 utáni egyiptomi események hogyan hatottak a líbiai változásokra, valamint az egyiptomi politikai változások hogyan alakították át szerepvállalását a líbiai polgárháború három szakaszában. Az egyiptomi belpolitikai válság miatt az ország külpolitikai mozgástere korlátozott volt 2011-2013 között. A stabilizációt követően mostanra körvonalazódtak az egyiptomi külpolitika prioritásai, amelynek a terrorizmus elleni küzdelem mellett, az afrikai kontinensen zajló események a legfontosabb elemei, illetve Egyiptom regionális szerepének megerősítése. A líbiai konfliktus rendezésében való részvétel kiemelt fontosságú a Szíszi-kormányzat számára, azonban továbbra is érzékelhetö, hogy az egyiptomi belpolitikai válság miatt a megkésett bekapcsolódás lemaradást eredményezett, amit nehezen tud leküzdeni az egyiptomi vezetés. Mindemellett Egyiptom Líbiával kapcsolatos döntéseit nemcsak az ország nemzetbiztonsági és kormányzati érdekei alakítják, hanem függőségi viszonyai miatt a szövetségesei elvárásai is.

\section{Az arab tavasz egyiptomi és líbiai következményei}

Egyiptom a közel-keleti és észak-afrikai (MENA-) térség egyik kulcsállama. Meghatározó szerepe a 2011-es arab tavasz során is megfigyelhető volt, az egyiptomi események közvetett hatást gyakoroltak a környező államokra. Ez a líbiai események kapcsán is érzékelhető volt, mert Hoszni Mubárak egyiptomi elnök lemondása után alig négy nappal, 2011. február 15-én kezdődtek Bengáziban azok a tüntetések, amelyeket már nem tudtak visszaszorítani a líbiai kormányerők. ${ }^{4} \mathrm{Az}$ egyiptomi vezetéssel ellentétben Kaddáfi nem távozott a hatalomból, ami a líbiai polgárháború 2011-es, első szakaszának kirobbanásához, majd a nemzetközi erők beavatkozásához és Kaddáfi 2011. októberi bukásához vezetett.

A líbiai polgárháború első szakaszával egy időben Egyiptomban a politikai átmenet súlyos belpolitikai válságot idézett elő az ideiglenes kormányzati szerepet betöltő Fegyveres Erők Legfelsőbb Tanácsa és a legerősebb politikai erővé előlépett Muszlim Testvérek között. Emiatt Egyiptom külpolitikai mozgástere beszükült, nem volt érdemi befolyása a lí-

Giuseppe Dentice: Egypt's Security and Haftar: al-Sisi's strategy in Libya. [online], 2017. 02. 02. Forrás: ispionline.it [2020. 05. 24.]

Kay Westenberger: Egypt's Security Paradox in Libya. [online], 2019. 04. 08. Forrás: e-ir.info [2020. 05. 24.]

Ian Black: Libya cracks down on protesters after violent clashes in Benghazi. [online], 2011. 02. 17. Forrás: theguardian. com [2020. 05. 24.] 
biai események alakulására. Mivel sokáig kétséges volt a líbiai polgárháború kimenetele, Egyiptom Tripolival kapcsolatos állásfoglalásai óvatosak voltak, bár Kaddáfi azzal vádolta az egyiptomi vezetést, hogy a keleti felkelőket támogatja. ${ }^{5}$ Ugyanakkor a polgárháború kezdetekor megalakult líbiai ellenzéki kormányt, az Átmeneti Nemzeti Tanácsot (National Transitional Council - NTC) Egyiptom csak azután ismerte el, hogy a nemzetközi beavatkozást követően a líbiai felkelők sikere körvonalazódott. ${ }^{6}$ Kairó és az Arab Liga - amelynek fótitkári posztját akkor Egyiptom töltötte be - szintén támogatta az ENSZ Biztonsági Tanács 1973-as határozatának elfogadását, amely a repüléstilalmi zóna létrehozására és a nemzetközi beavatkozás lehetőségére adott felhatalmazást. ${ }^{7}$ A nemzetközi erők segítségével a líbiai polgárháború első szakasza 2011. október 20-án végleg eldőlt, miután a lázadók Szirt városában elfogták és megölték Muámmár Kaddáfit.

A líbiai diktátor halálakor Egyiptomban már az első demokratikus parlamenti választásokra készültek. Az egyiptomi Muszlim Testvérek Szabadság és Igazságosság Pártjának jelentős társadalmi támogatottsága volt és nagyarányú győzelmet aratott, majd az elnökválasztáson is az általuk támogatott jelölt szerzett többséget. A Testvérek jelöltje, Mohamed Murszi 2012. június 30-án lépett hivatalba az ország új elnökeként. Murszi alig egy évig tartó elnöki ciklusa alatt a belpolitikai és gazdasági válság tovább mélyült Egyiptomban. ${ }^{8}$ Ezzel szinte egy időben, 2012 júliusában került sor Líbia átmeneti törvényhozó testületének megválasztására: az Általános Nemzeti Kongresszus (General National Congress - GNC) 18 hónapra kapott felhatalmazást. ${ }^{9}$ A líbiai választásokon a Muszlim Testvérek líbiai szárnya egyiptomi mintára létrehozta az Igazság és Építés elnevezésű pártját, amelynek, bár nem volt akkora támogatottsága, mint Egyiptomban, a választásokon másodikként végzett. Számos független képviselőt is a maguk oldalára állítottak, így jelentős befolyásra tettek szert Líbiában: ${ }^{10}$ többek között elérték, hogy a líbiai vezetés pénzügyi támogatást nyújtson a Muszlim Testvérek vezette Egyiptom számára 2013-ban. Mohamed Murszi 2013. júliusi megbuktatásáig úgy tűnt, hogy az egyiptomi átmenet nagyobb kihívásokkal küzd, mint

Telegraph: Libya Crisis: Egypt shipping arms across border to aid rebels. [online], 2011. 03. 18. Forrás: telegraph.co.uk [2020. 05. 25.]

6 Ahmed Eleiba: Egypt recognises Libya'S National Transitional Council. [online], 2011. 08. 22. Forrás: ahram.org.eg [2020. 05. 25.]; Átmeneti Nemzeti Tanács (National Transitional Council - NTC): Líbiai ideiglenes kormánya 2011. február 27-én Bengáziban alakult, elnöke a korábbi igazságügyi miniszter Musztafa Abdul Dzsalil volt. Az átmeneti kormány kérésére került sor a nemzetközi beavatkozásra az országban. 2012. augusztus 8-án oszlott fel, miután a kormányzati jogkört átadta a megválasztott Általános Nemzeti Kongresszusnak. Lásd bővebben: National Transitional Council [online], Forrás: ntclibya.org [2020. 05. 25.]

Yasmine Saleh: Arab Leauge chief says he respects U.N. resolution. [online], 2011. 03. 21. Forrás: reuters.com [2020. 05. 25.]

8 Hafez Ghanem: Egypt's Difficult Transition: Options for the International Community. [online], 2016. 07. Forrás: brookings.edu [2020. 05. 25.]

9 Általános Nemzeti Kongresszus: Líbia első demokratikusan megválasztott 200 tagú törvényhozó testülete, a líbiai kormány tagjait a testületből választották, amely az átmeneti időszakban a kormányzati feladatot látta el, valamint megválasztotta az alkotmányozó testületet. Az átmeneti kormánynak 18 hónap állt rendelkezésére az új alkotmány megírására, a népszavazás megtartására és a választások megszervezésére. Lásd bővebben: Jason Harmala: Libya’s Transition: The Current State of Play. [online], 2012. 11. 20. Forrás: atlanticcouncil.org [2020. 05. 25.]

10 The Carter Center: General National Congress Elections in Libya. [online], 2012. 07. 07. Forrás: cartercenter.org [2020. 05. 25.] 
Líbia. Azonban 2013. július 3-án az egyiptomi hadsereg vezetője, Abdel Fattáh esz-Szíszí vezetésével lemondásra kényszerítették Murszi elnököt, majd 2014 májusában megválasztották Egyiptom új vezetőjét, Abdel Fattáh esz-Szíszít, aki a hadsereg teljes támogatása mellett stabilizálta az egyiptomi belpolitikát, külpolitikájában pedig szorosra füzte kapcsolatait Szaúd-Arábiával és az Egyesült Arab Emírségekkel - a Muszlim Testvérek fö ideológiai és regionális ellenfeleivel. ${ }^{11}$

\section{Erősödő Egyiptom, széthulló Líbia: Egyiptom érdekei és szerepe a líbiai polgárháború második szakaszában}

Míg Egyiptom elindult a stabilizáció útján, Líbiában egyértelművé vált, hogy a megválasztott líbiai vezetés nagyon megosztott, és nem tudta uralni a fegyveres milíciákat, illetve kezelni a kiújuló ellentétet a keleti és nyugati országrészek között. Így továbbra is fokozódó instabilitás uralta az országot, lehetővé téve a szélsőséges csoportok térnyerését. 2014 januárjában lejárt az Általános Nemzeti Kongresszus mandátuma, viszont az ország új alkotmánya ekkorra sem készült el. Bár a törvényhozó testület ezt követően egy évvel még meghosszabbította saját felhatalmazását, azt már nem tudta kitölteni. ${ }^{12} 2014$ februárjában Halifa Haftar, a keleti országrész legjelentősebb katonai erejének, a Líbiai Nemzeti Hadseregnek (Libyan National Army - LNA) a parancsnoka puccsot kísérelt meg, majd 2014 márciusában a kormányválságot követően a GNC két frakcióra szakadt. ${ }^{13}$ Ahmed Maítik képviselte az iszlamista irányvonalat, őt elsősorban a nyugati országrész támogatta, míg a szekuláris nézetet és a keleti érdekeket az Abdullah ath-Thinni mögötti csoportosulás képviselte, valamint Haftar erői is az utóbbit támogatták. ${ }^{14} \mathrm{Az}$ ország fegyveres milíciái érdekeik szerint változtatták szövetségeiket a két oldallal. A Muszlim Testvérek fegyveres szárnyát képviselő tripoli fegyveres csoportok (Libyan Revolutionaries Operation Room - LROR) és az ország egyik legerösebb milíciája, a miszrátai Maítik mögött állt, míg a Zintán milícia ath-Thinnit támogatta, és Haftar tábornok is leginkább vele szimpatizált. ${ }^{15}$

Eközben az Iszlám Állam líbiai fiókszervezete is megjelent Dernában, majd Szirtben, valamint Bengáziban is erösödtek a radikális csoportok, többek között a Bengázi Forradalmi Súra Tanács és az Anszár as-Saría, ezért 2014 májusában Haftar megindította a keleti területeken a Méltóság hadműveletet, azzal a céllal, hogy megtisztítsa Bengázit

11 CNN: Egypt declares El-Sisi winner of presidential election. [online], 2014. 06. 04. Forrás: CNN.com [2020. 05. 25.]

12 Patrik Markey - Ghaith Shennib: In standoff, Libyans protest over parliment extension. [online], 2014. 02. 07. Forrás: reuters.com [2020. 05. 29.]

13 Anas El Gomati: Haftar's Rebranded Coups. [online], 2019. 07. 30. Forrás: carnegieendowment.org [2020. 05. 29.]

14 Marsai Viktor: A migrációs diskurzus margójára III. - A líbiai válság az európai migráció tükrében. [online], Nemzet és Biztonság, 12. (2019), 1. 110-134. Forrás: nemzetesbiztonsag.hu [2020. 05. 26.]

15 LROR: a Líbiai Forradalmárok Műveleti Központja nevü szervezet 2013-ban jött létre a Muszlim Testvérekhez köthető militáns csoportokból, vezetője a GNC 2013-ban megválasztott elnöke, Núri Abusahman. A szervezetet terroristaszervezetként tartják számon.

Miszrátai milícia: A miszrátai fegyveres csoportnak legalább 40 ezer tagja van, ezzel Líbia legerősebb fegyveres milíciája. A líbiai Iszlám Állam elleni küzdelemben kiemelt szerepe volt. 
a radikálisoktól. ${ }^{16}$ Május 18-án Haftar szövetségesei megtámadták a tripoli parlamentet, aminek következtében az iszlamisták mögött álló tripoli és miszrátai fegyveresek létrehozták a Líbiai Pajzs nevü szövetséget, és a Líbiai Hajnal művelet keretében ellentámadásba kezdtek. ${ }^{17}$ Végül 2014. augusztus végére el is foglalták Tripoli központját és a repteret.

Miután a GNC nem tudta megoldani a kormányválságot, 2014. június 25-én választásokat tartottak Líbiában, és megalakult a GNC-t leváltó Képviselőház (House of Representatives - HoR), amelynek többségét a szekuláris oldalt képviselők adták. Az eredményt az iszlamista frakció nem fogadta el, majd a Líbiai Legfelsőbb Bíróság is alkotmányellenesnek nyilvánította. ${ }^{18} \mathrm{Az}$ iszlamista képviselök továbbra is a GNC-t tartották legitimnek, ezért a HoR és az általa választott kormány Tobrukba és Bajdába helyezte székhelyét, mert Tripolit az iszlamista fegyveresek uralták.

A kettős kormányzás a keleti és nyugati országrészek közötti ellentét kiéleződéséhez, az Iszlám Állam líbiai térnyeréséhez és a líbiai polgárháború második szakaszának kirobbanásához vezetett. Az egyiptomi politikai visszarendeződés során és azt követően is prioritássá vált az egyiptomi vezetés számára a terrorizmus elleni küzdelem, amely elsősorban a Muszlim Testvérek visszaszorítását célozta, mivel Murszi elnök és a Muszlim Testvérek megbuktatását követően Egyiptomban jelentősen megnövekedett a terrorcselekmények száma. ${ }^{19}$ A keleti, gázai határnál a Hamász, míg nyugatról a líbiai szélsőségesek átszivárgása jelentette a legnagyobb fenyegetést Kairó számára. A 2014-ben kiéleződő líbiai belpolitikai válságban egyértelmü volt, hogy az egyiptomi katonai vezetés és később esz-Szíszí elnök politikai érdekeit és ideológiai nézeteit leginkább Halifa Haftar testesíti meg Líbiában. A kettős kormányzás időszakában Egyiptom a szekuláris irányultságú HoR-t támogatta, szemben a Muszlim Testvérekhez köthető GNC-vel.

A 2014 májusától eszkalálódó líbiai polgárháború rendezésében az ENSZ vállalt közvetítő szerepet, amelynek célja elsősorban az volt, hogy a két líbiai kormányzatból egy egységkormányt hozzon létre. 2015 januárjában kezdődtek az egyeztetések, majd az egy évig húzódó tárgyalássorozat eredményeképpen 2015. december 17-én a felek Szkírhátban aláírták a Líbiai Politikai Megállapodást. ${ }^{20} \mathrm{~A}$ megegyezést sürgette, hogy az Iszlám Állam időközben elfoglalta Szirt és Derna városát is, ezért szükség volt egy nemzetközileg elismert kormányzatra, amelyik kérheti a nemzetközi beavatkozást az ISIS visszaszorítására. ${ }^{21}$ A líbiai egységkormány vezetője Fáíz ász-Szarrádzs miniszterelnök lett, azonban a GNC

\footnotetext{
16 Az Iszlám Állam líbiai fiókszervezete 2014 novemberében jött létre Derna városában, miután Szíriából visszatért a líbiai harcosokból álló Battár Brigád, és létrehozta a Súra Tanács az Iszlám Fiataljaiért nevű szervezetet. Hozzájuk csatlakozott a Dernában szintén aktív radikális csoport, az Anszár as-Saría tagjainak jelentős része is, majd felesküdtek az Iszlám Államnak. A líbiai Iszlám Állam sejtjei megjelentek Szirt és Bengázi városokban is, de a szervezet nem tudott egybefüggő területet uralni Líbiában. Az ISIS líbiai szárnya szembekerült az al-Káidához kötődő radikális csoportokkal is, de a levantei területek legerősebb szatellitszervezete lett, és nagyszámú külföldi harcos csatlakozott hozzájuk. Mindezek ellenére nem rendelkeztek olyan erőforrások felett, mint az iraki szervezet. Lásd bővebben: Jason Pack - Rhiannon Smith - Karim Mezran: The Origins and Evolution of ISIS in Libya. [online], 2017. 07. 20. Forrás: atlanticcouncil.org [2020. 05. 26.]

17 Marsai (2019) i. m.

18 Mohamed Eljarh: The Supreme Court Decision That's Ripping Libya Apart. [online], 2014. 11. 06. Forrás: foreignpolicy. com [2020. 05. 23.]

19 Khaled Mahmud: Sisi's Ambitions in Libya. [online], 2018. 11. 30. Forrás: carnegieendowment.org [2020. 05. 29.]

20 Lásd bővebben: Libyan Political Agreement. [online], 2015. 12. 17. Forrás: unmissions.org [2020. 05. 26.]

21 Pack-Smith-Mezran (2017) i. m.
} 
és a HoR több vezető politikusa sem támogatta a megállapodást, és Halifa Haftar sem kapott szerepet. A líbiai hadsereg föparancsnoka az Elnöki Tanács vezetője lett, és a vezérkari fönök jelölése is az Elnöki Tanács hatáskörébe került. A kezdetektől látható volt, hogy az új vezetés nem oldja fel a hosszú távú belpolitikai ellentéteket. ${ }^{22}$

Egyiptom aktív szerepet vállalt a diplomáciai rendezésben. Az egyiptomi kormányzat bilaterális, regionális és nemzetközi szinteken is részese volt a tárgyalássorozatoknak, amelyek a líbiai rendezést szolgálták. Már a Líbiai Politikai Megállapodás elfogadását megelőzően, az Afrikai Unió és az Arab Liga támogatásával létrehozták a Líbiai Szomszédság Csoportot, hogy közösen segítsék a líbiai stabilizáció előmozdítását: a líbiai biztonsági szektor egyesítésére és a politikai diskurzus elősegítésére két munkacsoportban folyt az egyeztetés. ${ }^{23}$ A Szkírháti Megállapodás aláírását követően esz-Szíszí elismerte ugyan az új líbiai egységkormányt, azonban az általa preferált politikai erők elutasították azt. Egyiptom egy Líbia-Líbia párbeszéd megteremtésében látta a hosszú távú rendezés lehetőségét. A Líbiával kapcsolatos egyeztetések fórumaként esz-Szíszí kormánya létrehozta az Egyiptomi Líbia Bizottságot 2016 augusztusában. A líbiai rendezést illető elképzeléseit a 2016. novemberi afrikai uniós csúcstalálkozón vázolta, és vállalta a koordináló szerepet, valamint egy egyesített líbiai haderő létrehozásának szükségességét is kiemelte. Az egyiptomi vezetés számtalan egyeztetést folytatott a líbiai felekkel, ennek eredményeként 2016 decemberében elfogadták az első kairói deklarációt, amely módosítási javaslatokat tartalmazott a Szkírháti Megállapodással kapcsolatban, és ezekkel a feltételekkel a GNC és a HoR által létrehozott „ellenkormányok” is egyetértettek. ${ }^{24} \mathrm{~A}$ módosítások a katonai szervezetek vezetőivel kapcsolatos rendelkezéseket, illetve az Elnöki Tanács és Legfőbb Államtanács összetételének felülvizsgálatát érintették. A GNA azonban nem fogadta el a módosításokat, így nem történt látványos politikai elörelépés.

A diplomáciai rendezésben vállalt szerepe mellett Egyiptom és a szövetséges Egyesült Arab Emírségek is tevékenyen részt vállaltak Haftar 2014-ben indított Méltóság hadmüveletében, és azóta is katonai támogatást nyújtanak a líbiai tábornoknak. Az egyiptomi légierő 2015 februárjában kapcsolódott be a harcokba, miután az Iszlám Állam kivégzett 21 egyiptomi kopt állampolgárt Szirt közelében. ${ }^{25} \mathrm{~A}$ három évig húzódó Méltóság hadmüveletben Egyiptom szárazföldi erővel is részt vett, valamint később hozzásegítette Haftar csapatait Derna elfoglalásához, amiben az egyiptomi különleges erők támogatták az LNA-t. ${ }^{26}$ 2014 végére a Szíriából visszatérő harcosokból létrejött az ISIS líbiai szárnya Bengáziban, majd a szervezet beszivárgott Dernába is, azonban a helyi iszlamista csoportok fenyege-

22 International Crisis Group: The Libyan Political Agreement: Time for a Reset. [online], 2016. 11. 04. Forrás: crisisgroup. org [2020. 05. 26.]

23 Líbiai Szomszédság Csoportot 2014-ben hozták létre az Egyenlítői Guineában tartott Afrika csúcstalálkozó során. A kezdeményezésben részt vesz Algéria, Líbia, Egyiptom, Tunézia, Szudán, Csád és Niger. A szerveződés elsődleges célja, hogy Líbia közvetlen szomszédjai politikai és biztonságpolitikai támogatást nyújtsanak Líbiának, és megfékezzék a Líbiába áramló radikális csoportokat, amelyek az egész térség biztonságát veszélyeztetik. Lásd bővebben: State Information Service: Egypt's efforts to resolve Libyan crisis. [online], Forrás: sis.gov.eg [2020. 05. 26.]

24 Lobna Monib: Egypt's policy in Libya: A Government of National Accord by other means. [online], 2017. 01. 26. Forrás: madamasr.com [2020. 05. 29.]

25 Erin Cunningham - Heba Habib: Video shows purported beheading of Egyptian Christians in Libya. [online], 2015. 02. 15. Forrás: washingtonpost.com [2020. 05. 25.]

26 The New Arab: Egypt 'deploys special forces to Libya' to back Haftar. [online], 2017. 05. 30. Forrás: english.alaraby.co.uk [2020. 05. 29.] 
tésként tekintettek rájuk és kiszorították a városból, akik ezt követően, 2015 márciusában elfoglalták Szirtet. Az ISIS-t a GNC-t támogató miszrátai milícia próbálta meg kiszorítani Szirtből - kezdetben kevés sikerrel.

A líbiai egységkormány 2016 márciusában tért vissza Tripoliba, a miszrátai milícia pedig beállt az új vezetés mögé, majd 2016 májusában megindult a kormányerők ISIS elleni művelete, amelyhez Szarrádsz nemzetközi segítséget kért, és az Amerikai Egyesült Államok légi támogatásával 2016 decemberére sikerült kiszorítani Szirtből az ISIS-t. Bár a Méltóság hadmüvelet a terrorizmus elleni küzdelem jegyében zajlott, Haftar és az LNA nem csatlakozott a kormányerőkhöz az ISIS elleni müveletben, hanem nyugat felé terjeszkedett a szirti harcok idején, és 2016 szeptemberére elfoglalta a Szirthez közeli északi olajlétesítményeket. ${ }^{27} 2017$ végéig az LNA egyiptomi, emírségekbeli és orosz támogatással elfoglalta Dernát, majd Bengázit, így gyakorlatilag a keleti területeket Haftar uralta. Ezt követően a hadúr dél felé, Fezzán tartományban terjeszkedve folytatta „terrorellenes” műveleteit, amelyek valós célja a rivális fegyveres csoportok megtörése volt.

A líbiai belpolitikai válság egyre mélyült. 2017. februárban az egyiptomi diplomácia fáradozásainak ellenére nem sikerült elérnie, hogy ismét tárgyalóasztalhoz üljenek a felek. A kairói találkozó az egyiptomi támogatást élvező Haftar tábornok miatt hiúsult meg. Az Egyiptom által támogatott rendezési terv szerint az Elnöki Tanács létszámát 3 tagúra kellene csökkenteni, amelynek Szarrádzs, Szaláh és Haftár a tagja, a HoR és a Legfelsőbb Államtanács tagjaiból 15-15 fős közös bizottságot hozzanak létre a politikai konszenzus kialakítására, majd az alkotmánytervezet felülvizsgálatát és elfogadását követően az elnökés parlamenti választásokat a tervek szerint 2018 februárjában tarthatták volna. ${ }^{28}$ Haftar visszalépése a tárgyalásoktól az egyiptomi diplomácia tekintélyét is csorbította, a tábornok kiszámíthatatlan lépéseivel óvatosságra intette támogatóit. Oroszország azzal jelezte nem tetszését, hogy 2017 márciusában találkozóra hívta Fájíz asz-Szarrádzs elnököt. Ezt követöen végül 2017 májusában Abú Dzabiban megvalósult a találkozó a GNA, a HoR és az LNA vezetője között, amelyen a korábban említett egyiptomi találkozóra előkészített javaslatot tárgyalták meg. ${ }^{29}$

Ez az elképzelés az ENSZ rendezési tervébe is bekerült. 2017 júliusában Gasszán Szalamé lett az ENSZ líbiai különmegbízottja. Ekkorra egyértelművé vált, hogy a Líbiai Politikai Megállapodásban foglalt kétéves átmenet alatt az egységkormánynak nem sikerült egységet teremtenie az országban, a HoR és az Államtanács egymással versengve próbálta akadályozni a kormány erőfeszítéseit, ezért újra kell gondolni az átmenet lépéseit, ami előremozdíthatja a folyamatot. ${ }^{30}$ Szalamé 2017 szeptemberében ismertette új akciótervét a líbiai helyzet rendezésére, ami a Líbiai Politikai Megállapodás újragondolása volt. ${ }^{31} \mathrm{~A}$ ha-

\footnotetext{
Arab Center for Research and Policy Studies: The Scramble for the Oil Crescent and the Fight to Control Libya. [online], 2017. 03. Forrás: dohainstitute.com [2020. 05. 29.]

28 Lin Noueihed - Ahmed Mohammed Hassan: Egypt brokers Libya peace roadmap, but key figures fail to meet. [online], 2017. 02. 16. Forrás: reuters.com [2020. 05. 21.]

29 Marsai Viktor: Líbia agóniája. In Molnár Anna - Komlósi Orsolya (szerk.): Az Európai Unió Mediterrán térséggel összefüggő kapcsolata - Párbeszéd és konfliktusok. Budapest, Dialóg Campus, 2019. 89-90.

30 Karim Mezran: Libya Stuck in Transition. [online], IEMED Mediterranean Yearbook 2018. Forrás: iemed.org [2020. 05. 29.]

31 Lisa Watanabe: UN Mediation in Libya: Peace Still a Distant Prospect. [online], CSS Analyses in Security Policy, (2019), 246. 1-4. Forrás: css.ethz.ch [2020. 05. 29.]
} 
tékonyabb müködés elősegítésére háromtagúra csökkentette volna az Elnöki Tanácsot, majd a már említett HoR és az Államtanács tagjaiból létrehozott bizottságban újratárgyalta volna a Politikai Megállapodásban foglaltakat. Második lépésként egy nemzeti konferencia keretében tárgyalóasztalhoz ültette volna a líbiai feleket, hogy egy olyan államszervezetet építsenek ki, ahol a törvényhozás nem akadályozhatta volna a végrehajtó kormányt. Ezt követően került volna sor az új alkotmány népszavazással történő elfogadtatására, amit az elnök- és parlamenti választások követtek volna. A tervezett lépések megvalósítására egy év állt volna rendelkezésre. A HoR és az Államtanács nem támogatta az Elnöki Tanács létszámának csökkentését, ezért a folyamat megrekedt. Ennek ellenére a Líbiai Nemzeti Konferencia megszervezése továbbra is folyt, amit 2019 áprilisában tartottak volna, majd ezt követően júniusban került volna sor a parlamenti választásra. ${ }^{32}$

\section{A rendezés kudarca, a líbiai polgárháború harmadik szakasza}

Az ENSZ rendezésre tett újabb erőfeszítéseivel egy időben tovább eszkalálódott a helyzet Líbiában: Halifa Haftar folytatta müveleteit Fezzán tartományban, így az ország területének nagyobb része az LNA ellenőrzése alá került. ${ }^{33}$ A helyzet rendezésébe a líbiai befolyásra törekvő európai hatalmak is bekapcsolódtak, és 2018 májusában Emmanuel Macron francia elnök Párizsban tárgyalt a felekkel a választások megtartásáról, illetve a felek megállapodtak a tüzszünet megkötéséröl. ${ }^{34}$ Majd 2018 novemberében Olaszország adott otthont egy líbiai rendezésre irányuló csúcstalálkozónak Palermóban. ${ }^{35}$ Mindkét találkozó célja az volt, hogy Líbiában mihamarabb megtarthassák a választásokat. A tárgyalások ellenére 2018 decemberére Haftar erői elfoglalták a fezzáni olajlétesítményeket, ezzel az ország gazdaságának gerincét adó legjelentősebb kőolaj-kitermelőhelyek az LNA fennhatósága alá kerültek.

2019. április 4-én Haftar megkezdte a Tripoli elleni müveleteit, elfoglalta Garíjánt és a tripoli repteret. A müveletek megindítása előtt márciusban Haftar a szaúdi koronaherceggel is találkozott Ríjádban, és egyes hírek szerint a szaúdi vezetés jelentős anyagi támogatást nyújtott az LNA-nak az offenzívához. ${ }^{36}$ 2019. április 14-én az egyiptomi elnökhöz is ellátogatott Haftar tábornok, amikor Abdel Fattáh esz-Szíszí elnök is támogatást ígért a „terrorizmusellenes” müveletekhez. Azonban az LNA kezdeti sikerei nem vezettek gyors győzelemhez, annak ellenére sem, hogy Egyiptom, az Egyesült Arab Emírségek és Oroszország is segítette őket. A GNA májusban ellentámadással visszafoglalta Garíjánt, ezzel az LNA ellátási útvonala nagyon beszükült. 2019 decemberében Haftar bejelentette, hogy megindítja a végső nagy müveletet Tripoli elfoglalására, ezért a GNA Törökország beavatkozását kérte, és 2020 januárjában a török szárazföldi erők meg is érkeztek Tripoliba.

32 Emmadeddin Badi - Mohamed El-Jahr - Marwa Farid: At a Glance: Libya's Transformation 2011-2018: Power, Legitimacy and the Economy. [online], 2019. 04. Forrás: democracy-reporting.org [2020. 05. 30.]

33 Wolfram Lacher: International Schemes, Libyan Realities: Attempts at Appeasing Khalífa Haftar Risk Further Escalating Libya's Civil War. [online], SWP Comment, (2019), 45. 1-4. Forrás: swp-berlin.org [2020. 05. 30.]

34 Claudia Gazzini: Making the Best of France’s Libya Summit. [online], 2018. 05. 28. Forrás: crisisgroup.org [2020. 05. 30.]

35 Giovanna Di Maio: The Palermo Conference on Libya: A Diplomatic Test for Italy's New Government. [online], 2018. 11. 19. Forrás: brookings.edu [2020. 05. 30.]

36 Al Jazeera: Saudis gave Libya's Haftar millions of dollars before offensive. [online], 2019. 04. 13. Forrás: aljazeera.com [2020. 05. 30] 
Törökország bekapcsolódásával kiegyenlítődtek az erőviszonyok, és Haftar offenzívája megrekedt.

A Tripoli elleni offenzíva zsákutcába juttatta az ENSZ diplomáciai rendezésre tett kísérletét. 2019 júliusában Gasszán Szalamé három pontot tartalmazó javaslatot nyújtott be, amely szerint az erőszak megfékezésére tüzszünet megkötésére szólította fel a feleket, majd egy nemzetközi konferencia keretében újrafogalmazzák a lehetséges politikai megoldás feltételeit, hogy végül megtarthassák az áprilisra tervezett Nemzeti Konferenciát. Ez a tüzszünet nagyon rövid életű volt, de a harcok kimenetelében nem történt jelentős előrelépés. 2020. január 19-én került sor a berlini konferenciára, amelyen meghatározták a politikai rendezéshez való visszatérés lépéseit. ${ }^{37}$ Ezt megelőzően Törökország és Oroszország tűzszüneti megállapodás megkötésére bíztatta a feleket, azonban Halifa Haftar nem írta alá a megállapodást. Haftar nem volt érdekelt egy új egységkormány megteremtésében, és bár megjelent az ENSZ által szervezett konferencián, de továbbra is a katonai győzelem volt a végső célja. ${ }^{38}$

Törökország beavatkozását követően Haftar Tripoli elfoglalását célzó terveinek megvalósítása egyre messzebb került: 2020 áprilisában a GNA török támogatással elkezdte viszszaszorítani Haftar erőit a nyugati területeken. A veszteségek miatt fokozódott a feszültség Haftar és az őt támogató HoR között. A HoR vezetője, Akíla Szalah kísérletet tett a politikai rendezéshez való visszatérésre, amikor 2020. április 25-én nyolc pontból álló nyilatkozatot adott ki, amelyben gyakorlatilag a Gasszán Szalamé és az ENSZ által támogatott megoldást szorgalmazta, ebben azonban Haftar szerepe nem volt nevesítve. ${ }^{39}$ Erre reagálva Haftar újabb sikertelen puccsal próbálkozott. ${ }^{40} \mathrm{~A}$ tábornok katonai sikereket nem tudott felmutatni, ami kétségeket keltett támogatóiban. Miután a GNA visszafoglalta Szabrátát és Szurmánt, offenzívát indítottak az al-Watíja légibázis ellenőrzéséért, amelyet az LNA 2014-ben foglalt el. 2020. május 18-án a GNA török támogatással elfoglalta az LNA számára stratégiai fontosságú repteret, ezzel Haftar erőinek lehetőségei beszűkültek Tripoli környékén, és nehézkessé vált a logisztikai támogatásuk, így az LNA visszavonult Tripoli külső kerületeiből. ${ }^{41}$ 2020. június 4-én Haftar Tripoli elleni müveletének utolsó bástyája is elesett, miután a GNA Tarhúna városát is ellenőrzése alá vonta. ${ }^{42}$

Haftar kudarcait követően, 2020. június 6-án Egyiptom a líbiai konfliktus megoldására politikai rendezési javaslattal állt elő, amelynek első lépése az általános tűzszünet kihirdetése volt, ami 2020. június 8-án lépett volna életbe. A Kairói nyilatkozat továbbra is háromtagú elnöki tanács felállítását szorgalmazta, a korábbi elképzeléshez képest annyiban

37 Presse- und Informationsamt der Bundesregierung: The Berlin Conference on Libya: Conference Conclusions. [online], 2020. 01. 19. Forrás: unsmil.unmissions.org [2020. 05. 30.]

38 Karim Mezran: Importing Instability? How External Influences Nurture the War in Libya. [online], IAI Commentaries, (2020), 31. 1-6. Forrás: iai.it [2020. 05. 30.]

39 Sami Saptia: HoR head Ageela Saleh proposes 8-point political initiative. [online], 2020. 04. 25. Forrás: libyaherald.com [2020. 05. 30.]

40 Al Arabiya News: Libyan National Army’s Haftar claimes “mandate from the people”. [online], 2020. 04. 28. Forrás: alarbiya.net [2020. 05. 30.]

${ }^{41}$ France24: Haftar's forces pull out of parts of Tripoli after losing strategic airbase. [online], 2020. 05. 20. Forrás: france24. com [2020. 05. 30.]

42 Al Jazeera: Libyan government forces seize Haftar stronghold Tarhuna. [online], 2020. 06. 05. Forrás: aljazeera.com [2020. 06. 05.] 
módosítva, hogy a tagok a három régiót képviseljék; ez egybecsengett Szalah áprilisban felvázolt tervével. Az egyiptomi terv az átmeneti időszakot másfél évben határozta meg. ${ }^{43}$

A GNA és török szövetségese elutasította az egyiptomi javaslatot, Szirt és az el-dzsufrai katonai bázis visszafoglalását tűzték ki célul, illetve a tüzszünet megkötésének feltételeként szabták, hogy Haftar vonja vissza az LNA eröit Szirt városából. ${ }^{44}$ A stratégiai jelentőségü városokat egyik fél sem akarta feladni, megkezdődtek a müveletek Szirt elfoglalására, 2020. június 11-re a GNA eröi pedig elérték a város peremét. 2020. június 20-án az egyiptomi elnök ellátogatott a líbiai határ mellett található nyugati katonai körzetbe, ahol bejelentette, hogy Egyiptom kész közvetlenül beavatkozni Líbiában, amennyiben a GNA és a török erők átlépik a Szirt és El-Dzsufra vonalat, mivel ez közvetlen nemzetbiztonsági fenyegetést jelentene Egyiptom számára. ${ }^{45}$ Az egyiptomi parlament 2020. július 20-án megszavazta a felhatalmazást az egyiptomi haderő külföldi alkalmazására, a lehetséges beavatkozás nemzetközi legitimitását a HoR és a keleti törzsi vezetők felkérése biztosítja Egyiptom számára. ${ }^{46}$

Szirtben és El-Dzsufrában folytatódtak az összecsapások júniusban és júliusban, eközben háttértágyalások folytak a politikai rendezés lehetőségeiről. Németország külügyminisztere és az Egyesült Államok líbiai nagykövete is tárgyalásokat kezdeményezett a GNA és a HoR vezetőivel egy azonnali általános tüzszünet megkötéséről és Szirt demilitarizált övezetté nyilvánításáról, valamint az olajterminálok megnyitásáról. Az Egyesült Államok is támogatta a Kairói nyilatkozatot, ami visszatérést jelenthetne az ENSZ által kezdeményezett rendezési folyamathoz. ${ }^{47} \mathrm{~A}$ líbiai feleket támogató külső hatalmaknak sem volt érdekük a háborús eszkaláció, ezért a GNA-t támogató Törökország és a HoR, valamint a Haftar mögött álló Oroszország is tárgyalóasztalhoz ült a líbiai helyzet megvitatására.

A külső nyomás mellett a líbiai társadalomban is fokozódott az elégedetlenség: mind a keleti, mind a nyugati országrészben tüntetések voltak az egyre romló életkörülmények és az állandó áramkimaradások miatt. 2020. augusztus 21-én Fáíz asz-Szarrádzs és Akíla Szalah külön nyilatkozatban jelentették be az általános tüzszünetet. ${ }^{48} \mathrm{Az}$ ENSZ újonnan megválasztott líbiai különmegbízottja, Stephanie Williams és a Líbiával szomszédos államok közvetítőként támogatják a líbiai felek erőfeszítéseit a politikai rendezés előmozdításában. A HoR és a Legfelső Államtanács (HSC) tagjai 2020 szeptemberében Bouznikaban, Montreux-ben és Kairóban is találkoztak, hogy kidolgozzák a politikai átmenet lépéseinek kompromisszumos feltételeit. A 2020. szeptember 10-13. között Kairóban tartott

43 France24: Egypt announces new plan to end war in Libya as Haftar offensive loses ground. [online], 2020. 06. 06. Forrás: france24.com [2020. 06.08.]

44 Szirt és El-Dzsufra városok stratégiai jelentőségüek. A két város a keleti és nyugati országrész határán fekszik. Szirt jelentőségét növeli, hogy a város felől megközelíthetőek az ország legnagyobb olajlétesítményei, míg El-Dzsufrában található az ország legnagyobb katonai bázisa. Lásd bővebben: Naval Sayed: Strategic Significance of Libya’s Sirte, Jufra. [online], 2020. 06. 21. Forrás: see.news [2020. 06. 21.]

45 Noha El Tawil: Possible Egyptian 'direct' intervention in Libya becomes legitimate: President Sisi. [online], 2020. 06.20. Forrás: egypttoday.com [2020. 06. 21.]

46 Mohammed Al-Shamaah: Libyan tribes to El-Sisi: 'We need Egyptian support to expel Turkish colonizer'. [online], 2020. 07. 16. Forrás: arabnews.com [2020. 07. 24.]

47 Sami Zaptia: U.S continues pushing for Libya peaceful solution in Cairo and with HoR's Saleh [online], 2020. 08.11. Forrás: libyaherald.com [2020. 08. 21.]

48 Al Arabiya News: Libya's warring parties declare ceasefire: Statements. [online], 2020. 08. 21. Forrás: alarabiya.net [2020. 08. 21.] 
megbeszéléseik során a HoR és a HSC elfogadta a politikai átmenet ütemtervét, valamint 2021. októberre határozták meg a líbiai választások céldátumát. ${ }^{49} 2020$. szeptember 16-án asz-Szarrádzs bejelentette, hogy lemond az elnöki tisztségről, amint a líbiai párbeszéd bizottsága megválasztja az új Elnöki Tanácsot. ${ }^{50}$ 2020. szeptember 20-án orosz közvetítéssel Szocsiban találkozott Haftar és a GNA elnökhelyettese, Ahmed Maítik. A felek megállapodtak az olajlétesítmények nyolc hónapja tartó blokádjának feloldásáról, amely eddig közel 9 milliárd dollár veszteséget jelentett az ország számára. ${ }^{51}$ A politikai párbeszéddel párhuzamosan a líbiai biztonsági erők vezetése is tárgyalásokat folytatott, első megbeszélésükre 2020. szeptember 28-29-én került sor Hurghadában. A tárgyalások során első lépésként megállapodtak néhány bizalomerősítő intézkedésről: a belföldi repülőjáratok újraindításáról a keleti és nyugati országrészek között, illetve az ország középső részén az utak megnyitásáról. A találkozó legfontosabb eredménye azonban az volt, hogy a GNA és az LNA katonai vezetése hajlandónak mutatkozott folytatni a berlini konferencián meghatározott tárgyalásokat a biztonsági szektort érintő kérdésekben.

Ezt követően egy asztalhoz ültek az öt + öt egyesített katonai bizottság vezető tisztviselői, és 2020. október 23-án Genfben aláírták a tüzszüneti megállapodást. Ezzel együtt elfogadták, hogy a felek visszavonják erőiket a frontvonalról, valamint a keretfeltételeket az egyesített líbiai haderő létrehozásáról, illetve a fegyveres csoportok lefegyverzéséről és integrálásáról. Az egyezmény értelmében 90 nappal a tűzszüneti megállapodás után ki kell vonni a külföldi harcosokat az országból. ${ }^{52}$

Líbiában nagy reményeket füznek a tüzszüneti megállapodáshoz, habár a Haftar-ellenes erők szkeptikusak a megvalósulással kapcsolatban, és a líbiai Muszlim Testvériség is elutasítja, mert Haftart nem tekintik tárgyalópartnernek. Nemzetközi téren is többnyire pozitívan fogadták az előrelépést, de Törökország szerint nem lesz hosszú életü a megbékélés. ${ }^{53}$ A tárgyalások novemberben folytatódnak, hogy pontosítsák az elfogadott keretfeltételeket és azok gyakorlati megvalósítását, ami vélhetően több vitás kérdést is felszínre hoz. A bíztató jelek ellenére Líbiában nagyon törékeny a helyzet, a fegyvernyugvás megőrzéséhez minden líbiai félnek és külföldi támogatóiknak is be kell tartani a feltételeket.

\section{Összegzés és következtetések}

Egyiptom 2014 óta Haftar mögött állt, és bár nem ismeri el, de katonailag is segítette az LNA müveleteit a terrorizmusellenes küzdelem jegyében. Kairó kezdetben nem támogatta Haftar Tripoli elleni offenzíváját. Egyrészt azért, mert kevés esélyt látott arra, hogy sikerrel zárul, és egy elhúzódó polgárháború a nyugati határa mentén veszélyezteti biztonságát. Másrészt

49 Sami Zaptia: HoR and HSC Cairo delegations reach agreements - including constitutional elections by October 2021. [online], 2020. 09. 14. Forrás: libyaherald.com [2020. 10. 23.]

50 Daily Sabah: Libya's PM Sarraj says he wants to step down by end of October. [online], 2020. 09. 16. Forrás: dailysabah. com [2020. 10. 23.]

51 Al Jazeera: Haftar announces conditional lifting of Libya oil blockade. [online], 2020. 09. 18. Forrás: aljazeera.com [2020. 10. 23.]

52 Sami Zaptia: Immediate and permanent ceasefire agreement throughout Libya signed in Geneva. [online], 2020. 10. 23. Forrás: libyaherald.com [2020. 10. 23.]

53 International Crisis Group: Fleshing Out the Libya Ceasefire Agreement. [online], 2020. 11. 04. Forrás: crisisgroup.org [2020. 11.04.] 
Haftar a művelet megindításakor Líbia jelentős részét, valamint az ország legjelentősebb olajlétesítményeit is ellenőrzése alatt tartotta, ezzel maga mögé állította Franciaországot és Oroszországot is, ami jó tárgyalási pozíciót biztosított a líbiai tábornoknak.

Egyiptom támogatta Haftar politikai ambícióit, és a 2018-as ENSZ rendezési törekvéseket elősegítő, Egyiptom által kezdeményezett tárgyalások Haftar politikai pozícióba helyezését is célozták, azonban a tábornok ennél többet akart. Az Egyesült Arab Emírségek és Szaúd-Arábia a Tripoli elleni offenzíva megindítását sürgette. Egyiptom mindkét országgal a gazdaság és a kőolajellátás szempontjából is függőségi viszonyban van, fegyverbeszerzéseinek egy részét is azok finanszírozzák. Szövetségesei nyomására végül Kairó is beállt a líbiai tábornok mögé a Tripoli elleni támadásban. A kezdeti sikereket követően az egyiptomi kormány bízott abban, hogy Haftar mégis eléri a célját, mert ez Kairó számára kedvező politikai fordulatot hozott volna, és növelte volna líbiai és regionális befolyását is. Haftar elörenyomulása azonban alig néhány hónap alatt Tripoli külvárosaiban megakadt, és hónapokig nem történt elörelépés, majd a török beavatkozás végleg keresztülhúzta Haftar terveit.

A GNA erői török támogatással a korábbinál is nagyobb veszélyt jelentettek az egyiptomi kormányzat számára, ugyanis már nemcsak a líbiai Muszlim Testvérek és más iszlamista csoportok által is támogatott nyugat-líbiai kormány, de regionális riválisa is fenyegette. A török beavatkozásra reagálva a Haftar mögött sorakozó külföldi támogatók - Oroszország, Franciaország, az Egyesült Arab Emírségek és Egyiptom - is fokozták az LNA-nak nyújtott katonai támogatást. Májusra azonban egyértelművé vált Egyiptom és a többi külföldi patrónus számára is a tripoli művelet kudarca.

Bár Kairó hosszú távú érdekét egy egységes Líbia szolgálná, de biztonsági, gazdasági és társadalmi érdekei leginkább Líbia keleti területeihez kötik, ezért kiemelt egyiptomi érdekké vált, hogy befolyása megmaradjon Kireneikában. Ezért is kezdett tárgyalásokba 2020 áprilisában a líbiai Legfelső Törzsi Tanáccsal. ${ }^{54}$ Egyiptomnak ez a kezdeményezése egyes szakértők szerint irányulhatott alternatívakeresésre, hogy eltávolodhasson Haftartól, akinek társadalmi támogatottsága is gyengülőben volt a háború miatt. ${ }^{55}$ Azonban más vélemények szerint és a későbbi fejleményekböl arra is lehet következtetni, hogy a törzsi vezetők megnyerésével nemcsak saját kelet-líbiai befolyását akarta megerősíteni, de Haftar és az LNA támogatói bázisát is. ${ }^{56}$ Június elejére Haftar erői gyakorlatilag azokra a területekre szorultak vissza, amelyeket a tripoli művelet megindítása előtt is uraltak, a GNA és a török erők Szirt felé vették az irányt, ami a keleti területek és a legfontosabb olajlétesítmények felé vezető út kapuja. Ezt követően állt elő Egyiptom a politikai rendezésre tett kísérlettel a Kairói nyilatkozattal. Abban szerepelt az új Elnöki Tanács felállítása regionális alapon. A törzsek befolyása Kaddáfi bukása óta jelentősen növekedett, elsősorban a keleti régióban, mivel az állami intézmények nem tudták megfelelően ellátni funkcióikat, ezért vélhetően a keleti területeket egy Egyiptom számára is elfogadható jelölt képviselné.

54 Ariane Lavrilleux: Libya: what is behind the rise of the tribes?. [online], 2020. 08. 21. Forrás: theafricareport.com [2020. 08. 25.]

55 Mada Masr: UAE, Egypt prepare for Haftar's exit after loss of Wattiyah air base. [online], 2020. 05. 19. Forrás: madamasr. com [2020. 08. 25.]

56 Lavrilleux (2020) i. m. 
A GNA és Törökország elutasította az Egyiptom és Akíla Szalah által támogatott megállapodást és a fegyverszünetet, Szirt és El-Dzsufra elfoglalásáról nem akartak lemondani. Az egyiptomi diplomáciai erőfeszítések kudarcát követően Kairó katonai erő alkalmazását helyezte kilátásba, amennyiben a GNA és Törökország átlépi a Szirt és El-Dzsufra vonalat, ami a keleti területek határvonala. Az egyiptomi hadsereg erődemonstrálás céljából 2020. július 10-én nagyszabású hadgyakorlatot tartott, minden haderőnem felvonultatásával a líbiai határ mellett. ${ }^{57}$

Vélhetően csak a legvégső esetben avatkozna be Líbiában, mivel még mindig jelentős gazdasági nehézségekkel küzd az ország, a Sínai-félszigeten évek óta katonai műveletek zajlanak, ami leköti a hadsereg egy részét, és Etiópiával fennálló konfliktusa a nílusi gát kapcsán is rendezetlen. Mindemellett a koronavírus-járvány Egyiptomot sem kerülte el. Ezek tükrében nagy kockázatot jelentene, ha katonailag beavatkozna egy bizonytalan kimenetelü, akár évekig húzódó konfliktusba. Azonban a biztonsági, gazdasági, regionális és szövetségesi érdekei is megkövetelték a határozottabb fellépést. Az egyiptomi hadsereg alkalmazására nem került sor mostanáig, miután a nemzetközi közvetítéssel megvalósult háttértárgyalásoknak köszönhetően végül az eszkaláció helyett megindult a politikai rendezési folyamat, ami elsősorban az orosz-török tárgyalásoknak, valamint a német és amerikai közbenjárásnak volt köszönhető.

\section{FELHASZNÁLT IRODALOM}

Al Arabiya News: Libyan National Army's Haftar claimes "mandate from the people". [online], 2020. 04. 28. Forrás: alarabiya.net [2020. 05. 30.]

Al Arabiya News: Libya's warring parties declare ceasefire: Statements. [online], 2020. 08. 21. Forrás: alarabiya. net [2020. 08. 21.]

Al Jazeera: Haftar announces conditional lifting of Libya oil blockade. [online], 2020. 09. 18. Forrás: aljazeera. com [2020. 10. 23.]

Al Jazeera: Libyan government forces seize Haftar stronghold Tarhuna. [online], 2020. 06. 05. Forrás: aljazeera. com [2020. 06. 05.]

Al Jazeera: Saudis gave Libya’s Haftar millions of dollars before offensive. [online], 2019. 04. 13. Forrás: aljazeera. com [2020. 05. 30.]

Al-Shamaah, Mohammed: Libyan tribes to El-Sisi: 'We need Egyptian support to expel Turkish colonizer'. [online], 2020. 07. 16. Forrás: arabnews.com [2020. 07. 24.]

Arab Center for Research and Policy Studies: The Scramble for the Oil Crescent and the Fight to Control Libya. [online], 2017. 03. Forrás: dohainstitute.com [2020. 05. 29.]

Badi, Emmadeddin - Mohamed El-Jahr - Marwa Farid: At a Glance: Libya's Transformation 2011-2018: Power, Legitimacy and the Economy. [online], 2019. 04. Forrás: democracy-reporting.org [2020. 05. 30.]

Black, Ian: Libya cracks down on protesters after violent clashes in Benghazi. [online], 2011. 02. 17. Forrás: theguardian.com [2020. 05. 24.]

The Carter Center: General National Congress Elections in Libya. [online], 2012. 07. 07. Forrás: cartercenter.org [2020. 05. 25.]

CNN: Egypt declares El-Sisi winner of presidential election. [online], 2014. 06. 04. Forrás: CNN.com [2020. 05. 25.]

57 Fatma Lofti: Egypt continues 'Hasm 2020' drills on countering western border threats. [online], 2020. 07. 11. Forrás: dailynewsegypt.com [2020. 08. 25.] 
Cunningham, Erin - Heba Habib: Video shows purported beheading of Egyptian Christians in Libya. [online], 2015. 02. 15. Forrás: washingtonpost.com [2020. 05. 25.]

Daily Sabah: Libya's PM Sarraj says he wants to step down by end of October. [online], 2020. 09. 16. Forrás: dailysabah.com [2020. 10.23.]

Dentice, Giuseppe: Egypt's Security and Haftar: al-Sisi’s strategy in Libya. [online], 2017. 02. 02. Forrás: ispionline. it [2020. 05. 24.]

Di Maio, Giovanna: The Palermo Conference on Libya: A Diplomatic Test for Italy's New Government. [online], 2018. 11. 19. Forrás: brookings.edu [2020. 05. 30.]

Eleiba, Ahmed: Egypt recognises Libya'S National Transitional Council. [online], 2011. 08. 22. Forrás: ahram. org.eg [2020. 05. 25.]

El Gomati, Anas: Haftar's Rebranded Coups. [online], 2019. 07. 30. Forrás: carnegieendowment.org [2020. 05. 29.vg]

Eljarh, Mohamed: The Supreme Court Decision That's Ripping Libya Apart. [online], 2014. 11. 06. Forrás: foreignpolicy.com [2020. 05. 23.]

France24: Egypt announces new plan to end war in Libya as Haftar offensive loses ground. [online], 2020. 06. 06. Forrás: france24.com [2020. 06. 08.]

France24: Haftar's forces pull out of parts of Tripoli after losing strategic airbase. [online], 2020. 05. 20. Forrás: france24.com [2020. 05. 30.]

Gazzini, Claudia: Making the Best of France's Libya Summit. [online], 2018. 05. 28. Forrás: crisisgroup.org [2020. 05. 30.]

Ghanem, Hafez: Egypt's Difficult Transition: Options for the International Community. [online], 2016. 07. Forrás: brookings.edu [2020. 05. 25.]

Harmala, Jason: Libya's Transition: The Current State of Play. [online], 2012. 11. 20. Forrás: atlanticcouncil.org [2020. 05. 25.]

International Crisis Group: Fleshing Out the Libya Ceasefire Agreement. [online], 2020. 11. 04. Forrás: crisisgroup. org [2020. 11. 04.]

International Crisis Group: The Libyan Political Agreement: Time for a Reset. [online], 2016. 11. 04. Forrás: crisisgroup.org [2020. 05. 26.]

Lacher, Wolfram: International Schemes, Libyan Realities: Attempts at Appeasing Khalífa Haftar Risk Further Escalating Libya’s Civil War. [online], SWP Comment, (2019), 45. 1-4. Forrás: swp-berlin.org [2020. 05. 30.] DOI: https://doi.org/10.18449/2019C45

Lavrilleux, Ariane: Libya: what is behind the rise of the tribes?. [online], 2020. 08. 21. Forrás: theafricareport. com [2020. 08. 25.]

Lofti, Fatma: Egypt continues 'Hasm 2020' drills on countering western border threats. [online], 2020. 07. 11. Forrás: dailynewsegypt.com [2020. 08. 25.]

Mahmud, Khaled: Sisi’s Ambitions in Libya. [online], 2018. 11. 30. Forrás: carnegieendowment.org [2020. 05. 29.]

Markey, Patrik - Ghaith Shennib: In standoff, Libyans protest over parliment extension. [online], 2014. 02. 07. Forrás: reuters.com [2020. 05. 29.]

Marsai Viktor: A migrációs diskurzus margójára III. - A líbiai válság az európai migráció tükrében. [online], Nemzet és Biztonság, 12. (2019), 1. 110-134. Forrás: nemzetesbiztonsag.hu [2020. 05. 26.]

Marsai Viktor: Líbia agóniája. In Molnár Anna - Komlósi Orsolya (szerk.): Az Európai Unió Mediterrán térséggel összefüggő kapcsolata - Párbeszéd és konfliktusok. Budapest, Dialóg Campus, 2019. 77-94.

Masr, Mada: UAE, Egypt prepare for Haftar's exit after loss of Wattiyah air base. [online], 2020. 05. 19. Forrás: madamasr.com [2020. 08. 25.]

Mezran, Karim: Importing Instability? How External Influences Nurture the War in Libya. [online], IAI Commentaries, (2020), 31. Forrás: iai.it [2020. 05. 30.]

Mezran, Karim: Libya Stuck in Transition. [online], IEMED Mediterranean Yearbook 2018. Forrás: iemed.org [2020. 05. 29.]

Monib, Lobna: Egypt's policy in Libya: A Government of National Accord by other means. [online], 2017. 01. 26. Forrás: madamasr.com [2020. 05. 29.]

The New Arab: Egypt 'deploys special forces to Libya' to back Haftar. [online], 2017. 05. 30. Forrás: english.alaraby. co.uk [2020. 05. 29.] 
Noueihed, Lin- Ahmed Mohammed Hassan: Egypt brokers Libya peace roadmap, but key figures fail to meet. [online], 2017. 02. 16. Forrás: reuters.com [2020. 05. 21.]

Pack, Jason - Rhiannon Smith - Karim Mezran: The Origins and Evolution of ISIS in Libya. [online], 2017. 07. 20. Forrás: atlanticcouncil.org [2020. 05. 26.]

Presse- und Informationsamt der Bundesregierung: The Berlin Conference on Libya: Conference Conclusions. [online], 2020. 01. 19. Forrás: unsmil.unmissions.org [2020. 05. 30.]

Saleh, Yasmine: Arab Leauge chief says he respects U.N. resolution. [online], 2011. 03. 21. Forrás: reuters.com [2020. 05. 25.]

Sayed, Nawal: Strategic Significance of Libya's Sirte, Jufra. [online], 2020. 06. 21. Forrás: see.news [2020. 06. 21.]

State Information Service: Egypt's efforts to resolve Libyan crisis. [online], Forrás: sis.gov.eg [2020. 05. 26.]

Tawil, Noha El: Possible Egyptian 'direct' intervention in Libya becomes legitimate: President Sisi. [online], 2020. 06. 20. Forrás: egypttoday.com [2020. 06. 21.]

Telegraph: Libya Crisis: Egypt shipping arms across border to aid rebels. [online], 2011. 03. 18. Forrás: telegraph. co.uk [2020. 05. 25.]

United Nations Support Mission in Libya: Libyan Political Agreement. [online], 2015. 12. 17. Forrás: unmissions. org [2020. 05. 26.]

Watanabe, Lisa: UN Mediation in Libya: Peace Still a Distant Prospect. [online], CSS Analyses in Security Policy, (2019), 246. 1-4. Forrás: css.ethz.ch [2020. 05. 29.]

Westenberger, Kay: Egypt's Security Paradox in Libya. [online], 2019. 04. 08., Forrás: e-ir.info [2020. 05. 24.]

Zaptia, Sami: HoR and HSC Cairo delegations reach agreements - including constitutional elections by October 2021. [online], 2020. 09. 14. Forrás: libyaherald.com [2020. 10. 23.]

Zaptia, Sami: HoR head Ageela Saleh proposes 8-point political initiative. [online], 2020. 04. 25. Forrás: libyaherald. com [2020. 05. 30.]

Zaptia, Sami: Immediate and permanent ceasefire agreement throughout Libya signed in Geneva. [online], 2020. 10. 23. Forrás: libyaherald.com [2020. 10. 23.]

Zaptia, Sami: U.S continues pushing for Libya peaceful solution in Cairo and with HoR's Saleh. [online], 2020. 08. 11. Forrás: libyaherald.com [2020. 08. 21.] 